\title{
METHODS OF IDENTIFICATION OF THE LARVAE OF BALANUS BALANOIDES (L.), B. CRENATUS BRUG. AND VERRUCA STROEMIA O. F. MÜLLER
}

\author{
By K. A. Pyefinch \\ Biologist, The Corrosion Committee, British Iron and Steel Research Association. \\ From the Marine Station, Millport \\ (Text-figs. I-6) \\ CONTENTS

\begin{tabular}{|c|c|c|c|c|c|c|c|c|}
\hline & & & & & & & & PAGE \\
\hline NTRODUCTION & . & . & . & . & . & . & . & . $45 \mathrm{I}$ \\
\hline Che Characte & RISTICS of & F THE & E LARI & & StAges & . & . & . 452 \\
\hline $\begin{array}{l}\text { STINCTIONS } \\
\text { NOIDES, } B\end{array}$ & $\begin{array}{l}\text { BETWEEN } \\
\text {. CRENA? }\end{array}$ & $\begin{array}{c}\text { THE } \\
\text { TUS A }\end{array}$ & & & $\begin{array}{l}\text { OF BALA } \\
\text { UCA STR }\end{array}$ & $\begin{array}{l}\text { INUS } \\
\text { OEMIA }\end{array}$ & $\begin{array}{l}B A L A \text {. } \\
A \text {. }\end{array}$ & A- 455 \\
\hline JMMARY & . & . & . & . & . & . & . & . 462 \\
\hline BFERENCES & . & . & . & . & . & . & . & . 462 \\
\hline
\end{tabular}

\section{INTRODUCTION}

A review of the literature on barnacle larvae suggests that the information available falls roughly into two categories. A number of accounts are now available which give detailed descriptions of the full sequence of larval stages for a particular species. Willemoes-Suhm (1876) described the larval stages of Lepas fascicularis; Groom (I894) those of Balanus perforatus; Herz (1933) the larval stages of B. crenatus; Kühnert (1935) the larval stages of Alcippe lampas; Bassindale (1936) those of Balanus balanoides, Chthamalus stellatus and Verruca stroemia; Yasugi \& Ishida (I937) the free-swimming stages of Balanus amphitrite albicostatus; and Batham (1946) the larval stages of Pollicipes spinosus. As well as these fuller accounts, a number of references are available which describe and figure some of the larval stages; these range from the more comprehensive accounts of Hoek (I909) and Nilsson-Cantell (I92I), through shorter accounts in papers dealing more specifically with other topics (e.g. Runnström, 1925, 1926; Lochhead, I936), to brief descriptions of unidentified material (e.g. Stubbings, 1940).

Barnacle larvae, both nauplii and cyprids, are prominent components of the zooplankton in early spring and none of the sources of information just mentioned provides a means of rapid identification which would enable species and stages to be recognized when working through a plankton haul. Because of this difficulty, many workers have had to be content with recording the 
presence of Cirripede larvae without attempting further identification (e.g. Lebour, 1917; Marshall, 1925), others have made tentative identifications based on the identity of the commonest barnacles on the neighbouring shore (e.g. Moore, 1935), or on a knowledge of the spawning seasons of shore barnacles of the area studied (e.g. Fish, 1925).

In the course of biological work carried out in connexion with research on the fouling problem, studies have been made on the barnacle larvae occurring in the plankton at Millport. It has proved possible to discover characteristics which are sufficiently clear to be recognized at a glance under a lowpower binocular microscope, and which therefore enable the species and, to a considerable extent, the stage of barnacle larvae to be identified in situ in a dish of plankton.

The larvae of Balanus balanoides, B. crenatus and Verruca stroemia form the chief constituents of the Cirripede larvae in the plankton at Millport, and in this paper attention will be confined to methods for recognizing the larval stages of these three species. Other Cirripede larvae occur in much smaller numbers, in particular the nauplius of a species of Sacculina (probably $S$. carcini), the nauplius of a species of Peltogaster and nauplii and cyprids which may be those of Balanus porcatus. All these can be distinguished from the larval stages of the three species first mentioned, but knowledge of their appearance is too fragmentary to warrant their inclusion in the scheme set out below.

That the larval stages of only three species should be common in plankton hauls taken at Millport imposes, it is recognized, a disadvantage on the identification scheme set out later. Though these larval stages are fairly readily distinguishable inter se, some of them may resemble the larval stages of other species of barnacles, not present on the Clyde, so closely as to make this scheme difficult to use elsewhere. Inspection of the published figures of other species of barnacles does not suggest any obvious difficulties in this respect, but reasonable certainty that the characteristics suggested below are truly distinctive must await further work on the larvae of other species.

\section{The Characteristics of the LaRval Stages}

Balanus balanoides, B. crenatus and Verruca stroemia each pass through six naupliar stages before reaching the cyprid stage. Herz (1933) has described eight naupliar stages for Balanus crenatus, but Bassindale(1936) after reviewing the evidence put forward by Herz, concludes that 'it seems possible to regard the number of stages as not being perfectly established'. The present author has reared $B$. crenatus in the laboratory and has not been able to discover more than six naupliar stages so that it would appear that $B$. crenatus at Millport agrees with $B$. balanoides in possessing the same number of naupliar stages.

Outline diagrams of the six naupliar stages of $B$. balanoides are shown in Fig. I; these will be used to illustrate the characteristic features of each of these 

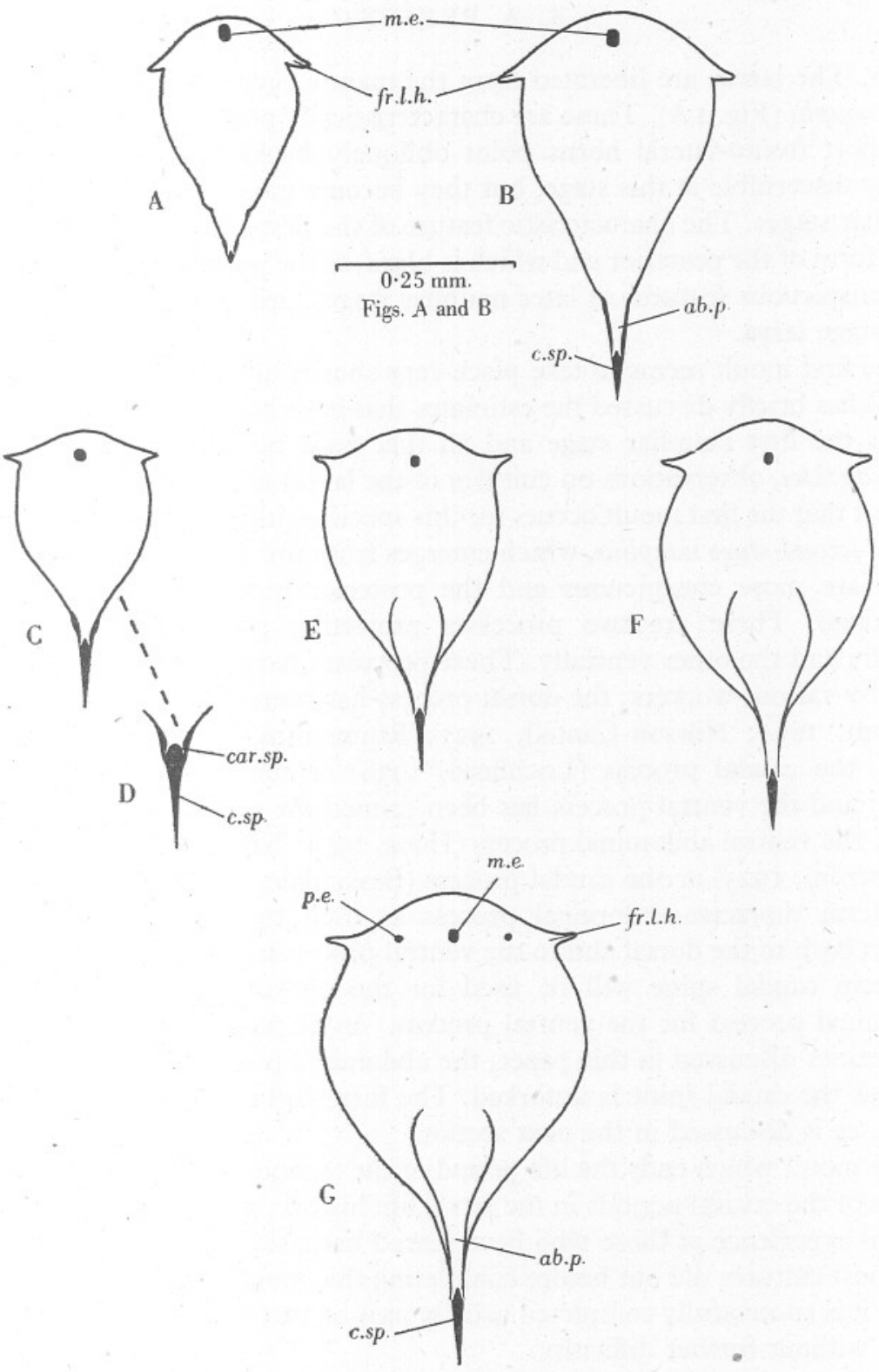

$0.5 \mathrm{~mm}$

Figs. C-C,

Fig. I. Outline diagrams of the six naupliar stages of Balanus balanoides in ventral view. A, first-stage nauplius; $\mathrm{B}$, second stage; $\mathrm{C}$, third stage; $\mathrm{D}$, dorsal view of hinder edge of carapace of third-stage nauplius, showing carapace spines; $\mathrm{E}$, fourth stage; F, fifth stage; $\mathrm{G}$, sixth-stage nauplius. $a b . p$. , abdominal process; c.sp., caudal spine; car.sp., carapace spine; fr.l.h., fronto-lateral horn; m.e., median eye; p.e., paired eye. 
stages. The larvae are liberated from the mantle cavity of the parent as firststage nauplii (Fig. I A). These are characteristically pear-shaped in outline and the short fronto-lateral horns point obliquely backwards. These horns are clearly discernible at this stage, but they become more prominent in the later naupliar stages. The characteristic feature of the first-stage nauplius, however, is the form of the posterior end which is blunt, as the posterior processes, which are conspicuous features of later naupliar stages, are barely developed in the first-stage larva.

The first moult seems to take place very shortly after hatching. Bassindale (1936) has briefly discussed the estimates that have been made of the length of life of the first naupliar stage and all that need be added here is that, for B. balanoides, observations on cultures of the larvae and plankton studies both suggest that the first moult occurs for this species within $24 \mathrm{hr}$. after liberation. In the second-stage nauplius, which emerges from this moult, the fronto-lateral horns are more conspicuous and the posterior processes are much better developed. There are two processes projecting posteriorly, one situated dorsally and the other ventrally. These processes have been named in various ways by various workers; the dorsal process has been termed the caudal spine (Groom, I894; Nilsson-Cantell, I921; Runnström, 1925; and Bassindale, 1936), the caudal process (Lochhead, 1936) or the carapace spine (Hoek, I909); and the ventral process has been termed the spinous process (Groom, I894), the ventral abdominal process (Hoek, I909; Nilsson-Cantell, I92I; and Runnström, 1925) or the caudal process (Bassindale, I936; Lochhead, 1936). The term thoracico-abdominal process as used by Herz (1933) evidently applies both to the dorsal and to the ventral processes. In the present account the term caudal spine will be used for the dorsal process, and the term abdominal process for the ventral process. In B. balanoides, as in the other two species discussed in this paper, the abdominal process is forked at its tip, whereas the caudal spine is unforked. The form and relationship of these two processes is discussed in the next section.

The moult which ends the life period of the second-stage nauplius seems to be one of the critical periods in the larval life history, since it appears to be the general experience of those who have reared barnacle larvae in the laboratory that most cultures die out before completing this moult, and those cultures in which it is successfully completed usually pass on through the remaining larval stages without further difficulty.

The form of the third-stage nauplius (Fig. IC) is generally similar to that of the second stage, though the fronto-lateral horns now project roughly at right angles to the long axis of the body. The chief distinguishing feature of this stage is the form of the carapace. In the earlier naupliar stages the carapace has no definite posterior margin, but is produced without interruption into the caudal spine. In the third-stage nauplius, however, the posterior border of the carapace is distinct and is further marked by the presence of two short, simple 
spines each of which projects backwards a short distance on each side of the mid-dorsal line (Fig. ID). These spines, which occur in the later naupliar stages both of $B$. balanoides and B. crenatus, are here termed carapace spines. In his diagrams of the outlines of the six naupliar stages of $B$. balanoides Bassindale (I936, fig. 2A, p. 59) does not figure these carapace spines, though he indicates the definite posterior margin of the carapace. They are present, however, in third-stage B. balanoides nauplii from the Clyde.

It is not at first easy to distinguish the fourth-and fifth-stage nauplii (Fig. IE, F) from the third-stage larvae, as the main difference between these three stages is one of size. If they occur together in a plankton haul (as frequently happens) distinction is not difficult, as the fifth-stage nauplius is roughly half as long again as the third-stage larva, but if only one stage occurs or if the numbers present are small, it may be necessary to measure individual larvae to check their stage. Practice, however, soon enables any one of these three stages to be recognized even if the other stages are not available for comparison. The swollen base of the abdominal process (within which the rudiments of the post-mandibular appendages can be discerned) helps to distinguish the fourth- and fifth-stage nauplii from the third stage, since this swelling first becomes obvious in the fourth-stage nauplius and is prominent in the succeeding stage. A careful examination of the third-stage nauplius, however, shows that the base of the abdominal process is slightly swollen in this stage also, so that this character is not diagnostic.

Finally, the sixth-stage nauplius (Fig. I G) can be recognized by the appearance of the paired eyes. The median eye, which has been present throughout the larval sequence, also persists in the sixth-stage nauplius. When the paired eyes are fully pigmented they are immediately obvious but it would seem that pigmentation proceeds slowly, probably during the life period of this naupliar stage, as some nauplii occur in which pigmentation is only just beginning and others in which the pigment is distinctly red in colour. When fully developed the pigment is black. This gradual development of pigmentation in the sixthstage nauplius is found not only in B. balanoides, but also in the corresponding stage of B. crenatus and Verruca stroemia.

It is more convenient to reserve a description of the characteristic features of the cyprid larva for the next section, where it will be compared with the corresponding stage of the other two species under discussion.

\section{DistinCtions BETWEEN THE LARVAE OF BALANUS BALANOIDES, B. CRENATUS AND VERRUCA STROEMIA}

Second-stage nauplii. Comparisons of the naupliar stages of Balanus balanoides, $B$. crenatus and Verruca stroemia can most profitably be made, in the first instance, between the second-stage nauplii. This is the most convenient stage for this purpose for two reasons: second-stage nauplii are those most frequently encountered in tow-nettings, and at this stage the main specific characteristics 

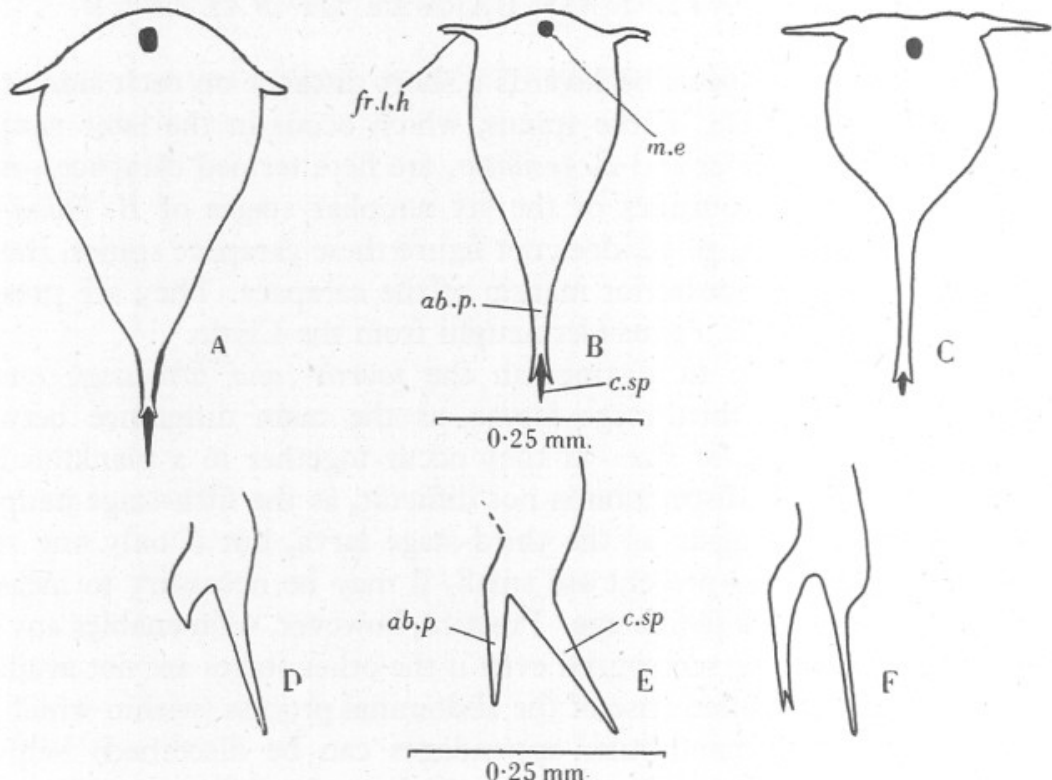

Fig. 2. Second-stage nauplii of (A) Balanus balanoides, (B) B. crenatus, and (C) Verruca stroemia, in ventral view; (D) Balanus balanoides, (E) B. crenatus, and (F) Verruca stroemia, lateral view of abdominal process and caudal spine. ab.p., abdominal process; c.sp., caudal spine; fr.l.h., fronto-lateral horn; m.e., median eye.

\section{Table I. Characteristics of the Second-Stage Naupliar Larvae}

\section{Character}

General shape (in ventral view)

Anterior margin

Fronto-lateral horns

Posterior processes
Short, pointing posteriorly

Balanus balanoides

Pear-shaped

Curved

Caudal spine much longer than abdominal process

Terminal fork of abdominal process with rami practically parallel

In lateral view, abdominal process taplike in form

\section{Balanus crenatus}

Triangular

Curved, but radius of curvature greater than that of B. balanoides

Moderately long, slightly curved, projecting roughly at right angles to main axis

Caudal spine longer than abdominal process

Terminal fork of abdominal process with rami making a distinct angle with each other

In lateral view, abdominal process slender, diverging markedly from caudal spine
Verruca stroemia Circular

Almost straight

Long and slender, projecting at right angles to main axis

Caudal spine either slightly longer than, or equal in length to, abdominal process

In lateral view, abdominal process and caudal spine practically parallel, or with former inclined towards latter 
are apparent so that a means of recognizing the identity of the second-stage nauplii provides a useful basis for distinguishing the specific identity of later stages.

Fig. 2A-C shows outline diagrams of these second-stage nauplii seen in ventral view, and Fig. $2 \mathrm{D}-\mathrm{F}$ shows the characteristics and relationships of the caudal spine and the abdominal process, as seen in lateral view. With these diagrams as illustrations, the distinguishing features of these nauplii can be listed as in Table I.

Using these characters, it is possible to recognize this stage of each of the three species under discussion virtually at a glance and distinction is further aided by the existence of other differences, less capable of precise description, but equally valuable as guides to identification. For example, the larvae of Balanus balanoides give an impression of bulk (this applies to all the naupliar stages, not only to the second stage) which produces a clumsy appearance, whereas the larvae of $B$. crenatus and Verruca stroemia are delicate and more transparent in appearance.

Later nauplii. Once the second-stage nauplii can be distinguished, the recognition of the specific identity of the later naupliar stages is not difficult as the main characteristics of the second-stage nauplii persist through the later naupliar stages, but there are a few complications which may cause some difficulty and therefore deserve mention.

The short, tap-like abdominal process of the second-stage nauplius of Balanus balanoides does not wholly retain this form through the later larval stages, since it becomes more elongated relative to the caudal spine. In the third-stage nauplius the ratio of the length of the caudal spine to that of the abdominal process is $3: \mathrm{I}$, but in the sixth-stage nauplius it has become $\mathrm{I} \cdot 7: \mathrm{I}$. As this ratio for the sixth-stage nauplius of $B$. crenatus is of the order of $I \cdot 3:$ I and as the abdominal process of the latter stage does not diverge so sharply from the caudal spine as in its second-stage larva-possibly owing to the swelling of the base of the abdominal process (see Fig. $3 \mathrm{C}$ ), an examination of the posterior region of the larvae in lateral view may not be very helpful. Distinction can be made, however, on the basis of general appearance, the form of the forked tip of the abdominal process and the dorsal outline. The later naupliar stages of $B$. balanoides fully retain the bulky appearance of the earlier stages and the tissues of formalin-preserved specimens often appear particularly dense, whereas the corresponding stages of $B$. crenatus retain their delicacy and transparency. The rami of the forked tip of the abdominal process of $B$. balanoides remain more parallel than those at the tip of the abdominal process of B. crenatus (Fig. $3 \mathrm{~B}, \mathrm{D}$ ), and the dorsal edge of the carapace is much more rounded in B. balanoides than it is in B. crenatus (Fig. $3 \mathrm{~A}, \mathrm{C}$ ).

The series of structural changes in the sequence of nauplii of Verruca stroemia is not quite the same as that of the nauplii of Balanus balanoides and $B$. crenatus. In the latter the third-stage nauplius can be distinguished from 
the earlier stages by the definite posterior margin of the carapace which bears the carapace spines. In Verruca stroemia the carapace does not acquire a definite posterior margin until the fourth-stage nauplius and this margin lacks
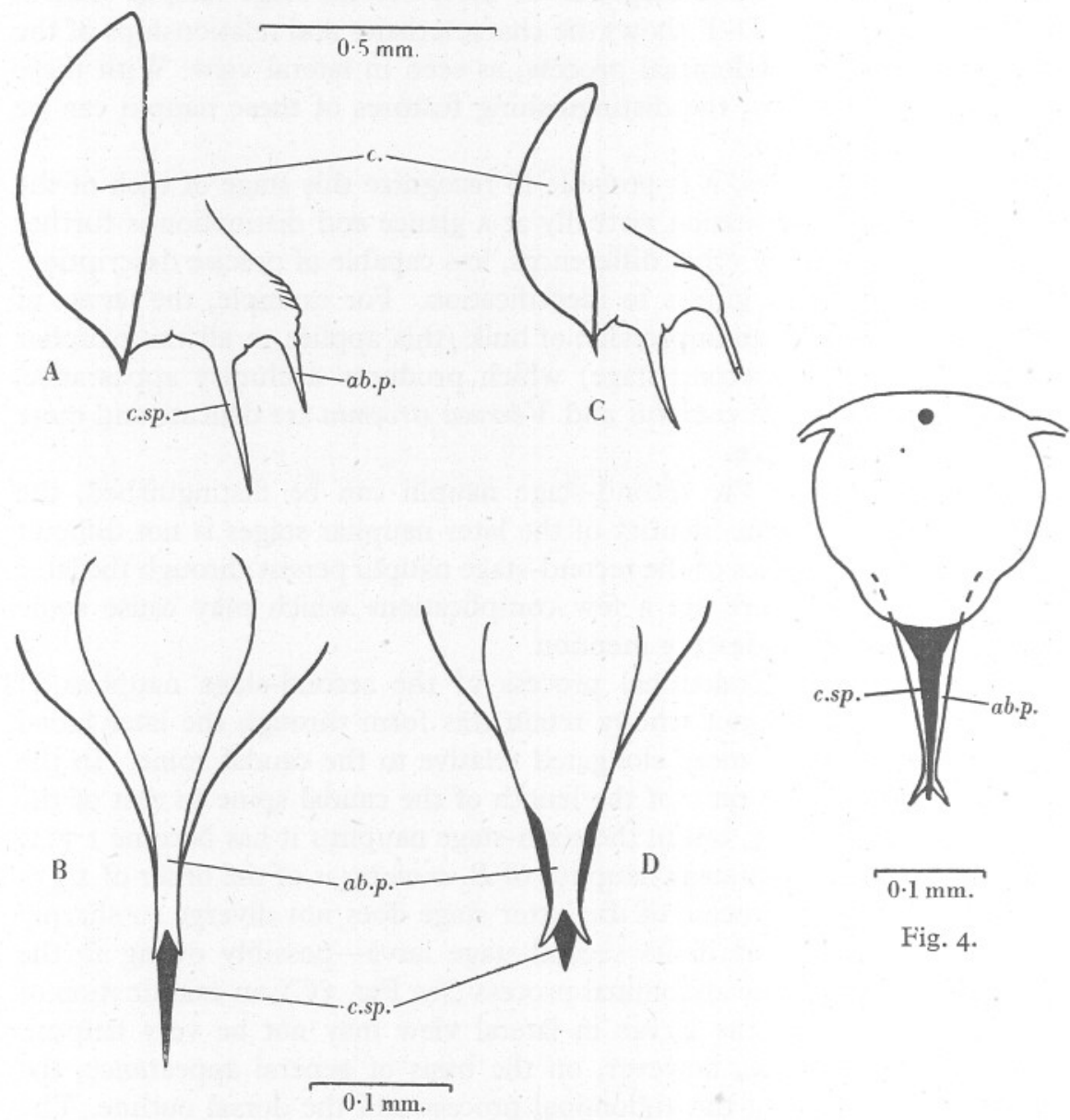

Fig. 3 .

Fig. 3. Sixth-stage nauplii of (A, B) Balanus balanoides, and (C, D) B. crenatus. Above, lateral view of nauplius; below, posterior processes enlarged in ventral view. ab.p., abdominal process; c., carapace; c.sp., caudal spine.

Fig. 4. Dorsal view of the fourth-stage nauplius of Verruca stroemia. The absence of carapace spines should be noted.

carapace spines, both in this and in the two succeeding naupliar stages (see Fig. 4). In $V$. stroemia, therefore, the fourth-stage nauplius is readily distinguished from the third stage, but the distinction between the second and third stages seems to be one of size only. Third-stage nauplii of $V$. stroemia do 
not seem to occur at all commonly in plankton hauls made at Millport, though Bassindale (1936) found this stage to be that which occurred most commonly in his cultures of the nauplii of this species.

Details of the lengths of the naupliar stages of the three species are given in Table II. Those for Balanus balanoides and Verruca stroemia are compared with those given by Bassindale (I936), which are given in parentheses below the measurements recorded in the course of the present survey. The range of variation in the length of these larvae from one place to another is unknown but in view of the known differences in size between cyprids of Balanus balanoides from different latitudes (see p. 46I), it would seem unwise to place too much reliance on the universal application of length measurements. In the present instance, these measurements are quoted to give an idea of the order of difference in length of the larval stages of the three species.

Table II. Lengths of the Naupliar Stages of B. Balanoides, B. CRENATUS AND $V$. STROEMIA

\begin{tabular}{|c|c|c|c|c|c|c|}
\hline \multirow[b]{2}{*}{ Stage } & \multicolumn{2}{|c|}{ B. balanoides } & \multicolumn{2}{|c|}{ B. crenatus } & \multicolumn{2}{|c|}{ V. stroemia } \\
\hline & $\begin{array}{l}\text { Full } \\
\text { length } \\
\text { (mm.) }\end{array}$ & $\begin{array}{c}\text { Carapace } \\
\text { length } \\
\text { (mm.) }\end{array}$ & $\begin{array}{l}\text { Full } \\
\text { length } \\
\text { (mm.) }\end{array}$ & $\begin{array}{c}\text { Carapace } \\
\text { length } \\
(\mathrm{mm} .)\end{array}$ & $\begin{array}{c}\text { Full } \\
\text { length } \\
(\mathrm{mm} .)\end{array}$ & $\begin{array}{c}\text { Carapace } \\
\text { length } \\
(\mathrm{mm} .)\end{array}$ \\
\hline Nauplius I & $\begin{array}{c}0.34 \\
(0.35)\end{array}$ & - & 0.28 & - & $(\overline{0.27)}$ & - \\
\hline Nauplius II & $\begin{array}{c}0.54 \\
(0.5 \mathrm{I})\end{array}$ & - & 0.44 & - & $\begin{array}{l}0.40 \\
(0.44)\end{array}$ & - \\
\hline Nauplius III & $\begin{array}{c}0.63 \\
(0.62)\end{array}$ & $\begin{array}{c}0.42 \\
(0.37)\end{array}$ & 0.57 & 0.35 & $\begin{array}{c}0.47 \\
(0.50)\end{array}$ & - \\
\hline Nauplius IV & $\begin{array}{c}0.76 \\
(0.69)\end{array}$ & $\begin{array}{c}0.54 \\
(0.4 \mathrm{I})\end{array}$ & 0.73 & 0.48 & $\begin{array}{c}0.54 \\
(0.58)\end{array}$ & $\begin{array}{c}0.31 \\
(0.34)\end{array}$ \\
\hline Nauplius V & $\begin{array}{c}0.92 \\
(0.8 \mathrm{I})\end{array}$ & $\begin{array}{c}0.63 \\
(0.53)\end{array}$ & 0.84 & 0.59 & $\begin{array}{c}0.62 \\
(0.63)\end{array}$ & $\begin{array}{c}0.39 \\
(0.37)\end{array}$ \\
\hline Nauplius VI & $\begin{array}{c}\mathrm{I} \cdot 05 \\
(\mathrm{I} \cdot \mathrm{I} 5)\end{array}$ & $\begin{array}{c}0.73 \\
(0.79)\end{array}$ & 0.91 & 0.63 & $\begin{array}{c}0.73 \\
(0.69)\end{array}$ & $\begin{array}{c}0.47 \\
(0.42)\end{array}$ \\
\hline
\end{tabular}

Measurements in parentheses are taken from Bassindale (I936).

First-stage nauplii. Outline diagrams of the first-stage nauplii of these three species are shown in Fig. 5, from which it will be evident that each differs considerably in appearance from its succeeding stages; this difference is probably least for the first-stage nauplius of $B$. balanoides. The brevity of the posterior processes seems to be the common characteristic of these three first-stage nauplii.

The first-stage larva of B. balanoides (Fig. 5A) gives promise of the bulky appearance that has been mentioned as a general characteristic of the later naupliar stages; there is nothing that can be added here to the description given earlier (p. 454). The first-stage larvae of B. crenatus (Fig. 5B) and Verruca stroemia (Fig. 5C) are, in spite of their evident differences shown in these outline diagrams, curiously easy to confuse when examining a plankton haul. 
Though the first-stage nauplius of $V$. stroemia has long, well-developed fronto-lateral horns, in formalin-preserved material these are often obscured by the first antennae, which lie over them (Fig. 5C)-it is interesting to find that this had evidently occurred in the specimen which Nilsson-Cantell (I92I) used for his figure of the first-stage nauplius of this species. With the frontolateral horns obscured in this way, there is little to distinguish the first-stage nauplii of $V$. stroemia and the corresponding stage of Balanus crenatus, in ventral view, except size. This confusion can, however, readily be resolved, for if the first-stage larva of Verruca stroemia is turned forwards, by a needle placed under the posterior processes, on to its anterior edge, the fronto-lateral

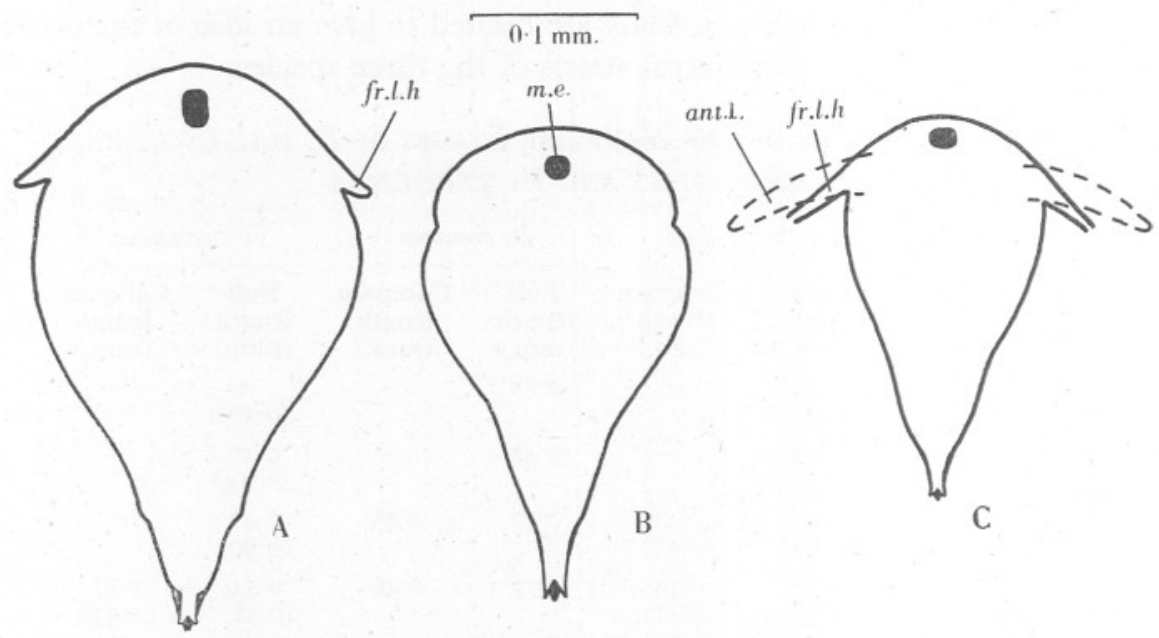

Fig. 5. First stage nauplii of (A) Balanus balanoides, (B) B. crenatus, and (C) Verruca stroemia in ventral view. ant.I, first antenna; fr.l.h., fronto-lateral horn; m.e., median eye.

horns are easily seen curving away from the body. Since the fronto-lateral horns of the first-stage nauplius of Balanus crenatus are closely bound to the sides of the carapace, this operation does not reveal their presence in this species.

Nilsson-Cantell (I92I) has emphasized the ease with which liberation of larvae can take place in the laboratory and has stressed the fact that therefore larval stages may occur under aquarium conditions which are not normally liberated under more natural circumstances. It should therefore be added that all the first-stage larvae described in this section have been recovered from plankton hauls in considerable numbers and there is little doubt that these stages are members of the series of stages normally present in the sea.

Cyprids. Diagrams of the outline of the cyprid larvae of these three species, shown in Fig. 6, indicate that there are considerable differences in size between them, the cyprid of $B$. balanoides (Fig. 6A) being the largest, that of Verruca stroemia (Fig. 6C) the smallest. 
Confusion is most likely to arise between the cyprid of Balanus balanoides and that of $B$. crenatus. The specimens chosen for Figs. $6 \mathrm{~A}$ and $6 \mathrm{~B}$ may be considered typical specimens of the two species of cyprids, but the limits of variation in length of the cyprids of the two species unfortunately are such that the biggest $B$. crenatus cyprids are as long as, or slightly longer than, the smallest cyprids of $B$. balanoides. Further, the cyprid of $B$. balanoides seems to vary in length with latitude; Runnström (1925) states that this larva is I.2 mm. long, whereas Bassindale (1936) found specimens collected at Plymouth to be $0.94 \mathrm{~mm}$. in length. Measurements of this cyprid from the plankton at Millport show that the length varied from 0.9 to I.I mm., though most lay within the range $0.98-\mathrm{I} \cdot 06 \mathrm{~mm}$. This suggests that the cyprid of $B$. balanoides attains a greater length in northern waters.

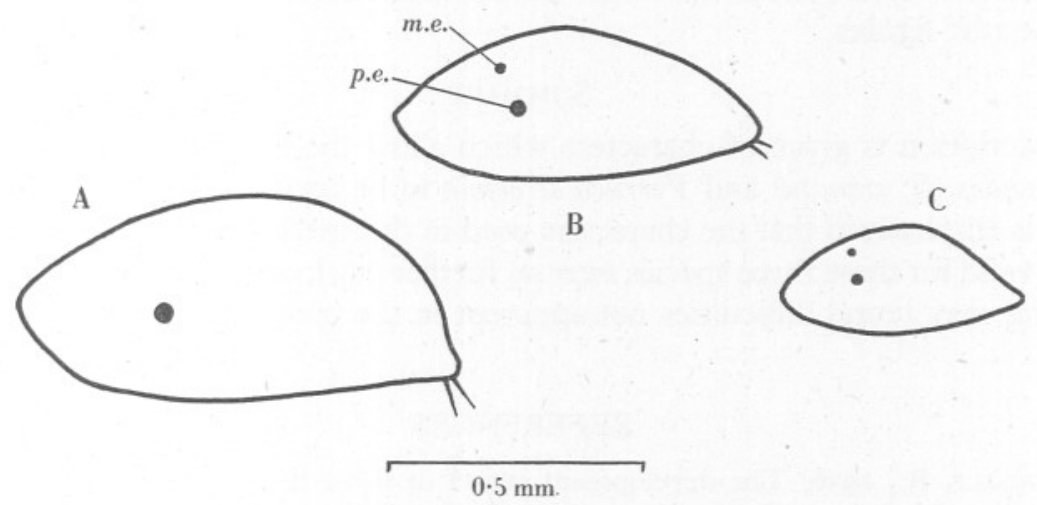

Fig. 6. Cyprid larvae of (A) Balanus balanoides, (B) B. crenatus, and (C) Verruca stroemia. m.e., median eye; p.e., paired eye.

Other characters can, however, be used to distinguish the cyprid of $B$. balanoides from that of $B$. crenatus. Typically, the former is brown in colour, whereas the latter is not coloured in this way. The degree of pigmentation of the cyprid of $B$. balanoides varies considerably, however, and some lightly pigmented specimens may not be easy to distinguish. In these the position of the eyes has proved a useful character. In the cyprid of B. balanoides the median eye lies at very much the same distance from the dorsal edge of the carapace, whereas in the cyprid of $B$. crenatus the paired eyes lie at a greater distance from the dorsal edge of the carapace than the median eye. Consequently, in lateral view, only one of the paired eyes can be seen in the cyprid of $B$. balanoides (Fig. 6A), whereas one of the paired eyes and the median eye can be seen in the cyprid of B. crenatus (Fig. 6B). The difficulties that may arise in distinguishing these two species of cyprids have been discussed at some length, as experience has shown that awkward specimens do occur, but it should be emphasized that they form only a small fraction of the whole and 
that it is possible to distinguish most B. balanoides cyprids from most B. crenatus cyprids at a glance.

One of the paired eyes and the median eye can also be seen when the cyprid of Verruca stroemia is seen from one side, but there is little chance of confusing this cyprid with that of Balanus crenatus as the difference in size is pronounced. Moreover, the dorsal border of the carapace of the cyprid of Verruca stroemia is practically straight posteriorly, whereas that of the cyprid of Balanus crenatus is distinctly rounded.

The author is indebted to the Marine Corrosion Sub-Committee of the British Iron and Steel Research Association for permission to publish this work and to Prof. J. E. Harris for his interest in it. He also wishes to record his grateful thanks to Dr R. B. Pike for his skilled assistance in the preparation of the text-figures.

\section{SUMMARY}

A description is given of characters which allow the larval stages of Balanus balanoides, B. crenatus and Verruca stroemia to be identified rapidly.

It is emphasized that the characters used in this method of identification are only valid for these three species inter se, further work on similar lines for other species may reveal difficulties not apparent in the present scheme.

\section{REFERENCES}

Bassindale, R., I936. The development stages of three English barnacles, Balanus balanoides (Linn.), Chthamalus stellatus (Poli) and Verruca stroemia (O. F. Müller). Proc. Zool. Soc. Lond., 1936, pp. 57-74.

Batham, E. J., I946. Pollicipes spinosus Quoy and Gaimard. II. Embryonic and larval development. Trans. N.Z. Roy. Soc., Vol. Lxxv, pp. 405-I8.

Fish, C. J., I925. Seasonal distribution of the plankton of the Woods Hole region. Bull. U.S. Bur. Fish. Washington, Vol. XLI, pp. 9I-I79.

Groom, T. T., I894. The life-history of the rock barnacle (Balanus). Fournal of Marine Zoology and Microscopy, Vol. I, pp. 8I-6.

Herz, L. E., I933. The morphology of the later stages of Balanus crenatus Brugière. Biol. Bull. Woods Hole, Vol. LxIv, pp. 432-42.

Hoek, P. P. C., I909. Die Cirripedien des nordischen Planktons. Nordisches Plankton, Bd. IV, No. 8, pp. 265-331.

KüHNERT, L., I935. Beitrag zur Entwicklungsgeschichte von Alcippe lampas Hancock. Zeits. f. Morph. u. Ök. der Tiere, Vol. xxIx, pp. 45-78.

Lebour, M. V., I9I7. The microplankton of Plymouth Sound from the region beyond the breakwater. Fourn. Mar. Biol. Assoc., Vol. xI, pp. 133-82.

LochHEAD, J. H., I936. On the feeding mechanism of the nauplius of Balanus perforatus Brugière. Proc. Linn. Soc. (Zool.), Vol. xxxix, pp. 429-42.

Marshall, S. M., I925. A survey of Clyde plankton. Proc. Roy. Soc. Edinb., Vol. xuv, pp. II7-4I.

Moore, H. B., I935. The biology of Balanus balanoides. III. The soft parts. Fourn. Mar. Biol. Assoc., Vol. xx, pp. 263-77. 
Nilsson-Cantell, C. A., I92I. Cirripedien studien. Zool. Bidr. Uppsala, Vol. xII, pp. $75-378$.

RunNSTRÖM, S., I925. Zur Biologie und Entwicklung von Balanus balanoides (Linné). Bergens Mus. Aarbok., Naturv. Raekke, Nr. 5.

- I926. Über die Plattenentwicklung von Verruca stroemia O. F. Müller. Bergens Mus. Aarbok., Naturv. Raekke, Nr. 3.

Stubbings, H. G., I940. Cirripedia (Additional Part). 'Fohn Murray' Exped. Sci. Repts., Vol. vir, pp. 383-99.

Willemoes-SuHm, R. von I876. On the development of Lepas fascicularis and the Archizoea of Cirripedia. Phil. Trans. Roy. Soc. London, Vol. CLXvI, pp. I3I-54.

*YASUGI, R. \& IsHIDA, S., I937. Free-swimming stages of $B$. amphitrite albicostatus. Botany and Zool. Tokyo, Vol. v, pp. I659-66.

* This reference has not been consulted personally. 